$\xi=-1$

\title{
Managing Employee Participation based on OSHA's Process Safety Management Requirements
}

\author{
Noor Diana Abdul Majid*, Dzulkarnain Zaini and Azmi Mohd Shariff \\ Centre of Advanced Process Safety (CAPS), Universiti Teknologi PETRONAS, 32610 Seri Iskandar, Perak Darul Ridzuan, Malaysia. \\ *Corresponding author E-mail: diana.majid@utp.edu.my/noordianamajid@gmail.com
}

\begin{abstract}
A report published on 25 April 2016 stated that OSHA has issued 14 serious violations after an investigation conducted in a variety of industries including manufacturing, water treatment and oil and gas that violated OSHA's Process Safety Management (PSM) standard. One of the violations is related to the 29 CFR 1910.119(c)(2) which is employers did not consult with employees and their representatives on the conduct and development of the OSHA's PSM elements which are process safety information (PSI), process hazard analyses (PHA), training (TNG), mechanical integrity (MI), management of change (MOC), pre-start up safety review (PSSR), contractors (CON), incident investigations (II), emergency planning and response (EPR), compliance audit (CA) and trade secret (TS). 29 CFR1910.119(c)(2) is one of the requirements in the OSHA's PSM employee participation element. However, companies are still struggling to comply with this regulation due to unclear coverage and the implementation method for achieving compliance. Thus, this paper presents a framework and work-aid tool developed based on OSHA's PSM 29 CFR 1910.119(c) which are helpful to the industries as they provide structured technique to plan and implement an employee's participation management system to achieve compliance in implementing the OSHA PSM employee participation element.
\end{abstract}

Keywords: Accident; Emergency planning and response; Employee participation; Incident; Near-miss; Process safety management; Workforce involvement.

\section{Introduction}

Employee Participation, also known as Workforce Involvement is placed at the top of the 14 PSM elements in the OSHA PSM standard. Employee Participation plays a vital role in PSM as the involvement of all employees at every level is fundamental to the success of such a program. Workers at all levels and positions in an organization have various roles, responsibilities, knowledge and expertise to fulfill process safety management system development, implementation, and enhancement to ensure the safety of the organization's operation. However, there is a lack of participation from employees as they may not be aware of their potential contribution in PSM. Some organizations may discourage workers from contributing their views as they find it as a nontraditional role which in turns degrade the full expertise capabilities [1].

After an investigation conducted in a variety of industries including manufacturing, water treatment and oil and gas [2], OSHA reported a violation on one of the requirements in the employee participation element of PSM standard (CFR 1910.119(c)(2)) whereby the employers did not consult with employees and their representatives on the conduct and development of the OSHA's PSM elements which are PSI, PHA, TNG, MI, MOC, PSSR, CON, II, EPR, CA and TS. In this investigation, employees were exposed to release of extremely flammable vapors to atmosphere that historically result in fire or explosion hazards leading to injury and death in the workplace [2]. The unclear employee participation caused many process safety issues such as unplanned releases of hazardous chemicals that leads to major accidents such as fires, explosions and toxic release which result in the loss of life, financial burden and also potential impact to the environment [2-3].

Although industries are aware about the importance of employee participation in the PSM program, they are not clear on the coverage and the best method to implement it according to the need of PSM OSHA 1990.119(c) requirements. Even the most sophisticated operators find compliance to PSM challenging due to the broad scope and highly technical nature of the 14 elements [4]. OSHA PSM regulation does not provide any specific technique for industries to follow and how detail the evidence should be provided as a proof of compliance. Open literatures regarding the technique, model and tool for employee participation in ensuring significant contribution of process safety and PSM compliances are very rare. There is clearly a lack of a proper system or model for employee participation that could be easily used by the industry to ensure compliance with PSM regulation.

Thus, this paper presents a structured and easy technique to plan and implement employee participation according to PSM regulation. A work-aid tool has been developed based on this technique, and its application has been verified with data from participation of the employer and employees for one of the PSM elements that is Emergency Response Plan (ERP) at Plant X in Malaysia.

\section{Methodology}

\subsection{Compliance with OSHA's PSM Standard}

Figure 1 shows the Employee Participation framework based on the interpretation of OSHA 29 CFR 1910.119(c). The implemen- 
tation of Employee Participation begins with selecting the PSM element to be developed. Once the PSM element has been selected, the employer needs to check the availability of the written plan of action ((29 CFR 1910.119(c)(1)). If the written plan is not available, the employer needs to develop the written plan of action on how the employee can perform the task of actions for the selected PSM element. The written plan should also include employee involvement in the conduct and development of PSM element. The next step is where the employer needs to engage the employee for consultation on the conduct and development of the PSM element (29 CFR 1910.119(c)(2)) based on the provided written plan. Active employees' participation in all the elements through consultation will enhance the overall PSM program. The last step is to allow the employees and the representatives to access all information (29 CFR 1910.119(c)(3)) that are deemed necessary to conduct and develop the PSM element. The PSM standard requires employees to have access to all information and materials for the development of the PSM element. Once the three main principles of Employee Participation have been accomplished, employees can start to develop and conduct the PSM element. The cycle continues until the requirements of Employee Participation element is developed and conducted for all other PSM elements.

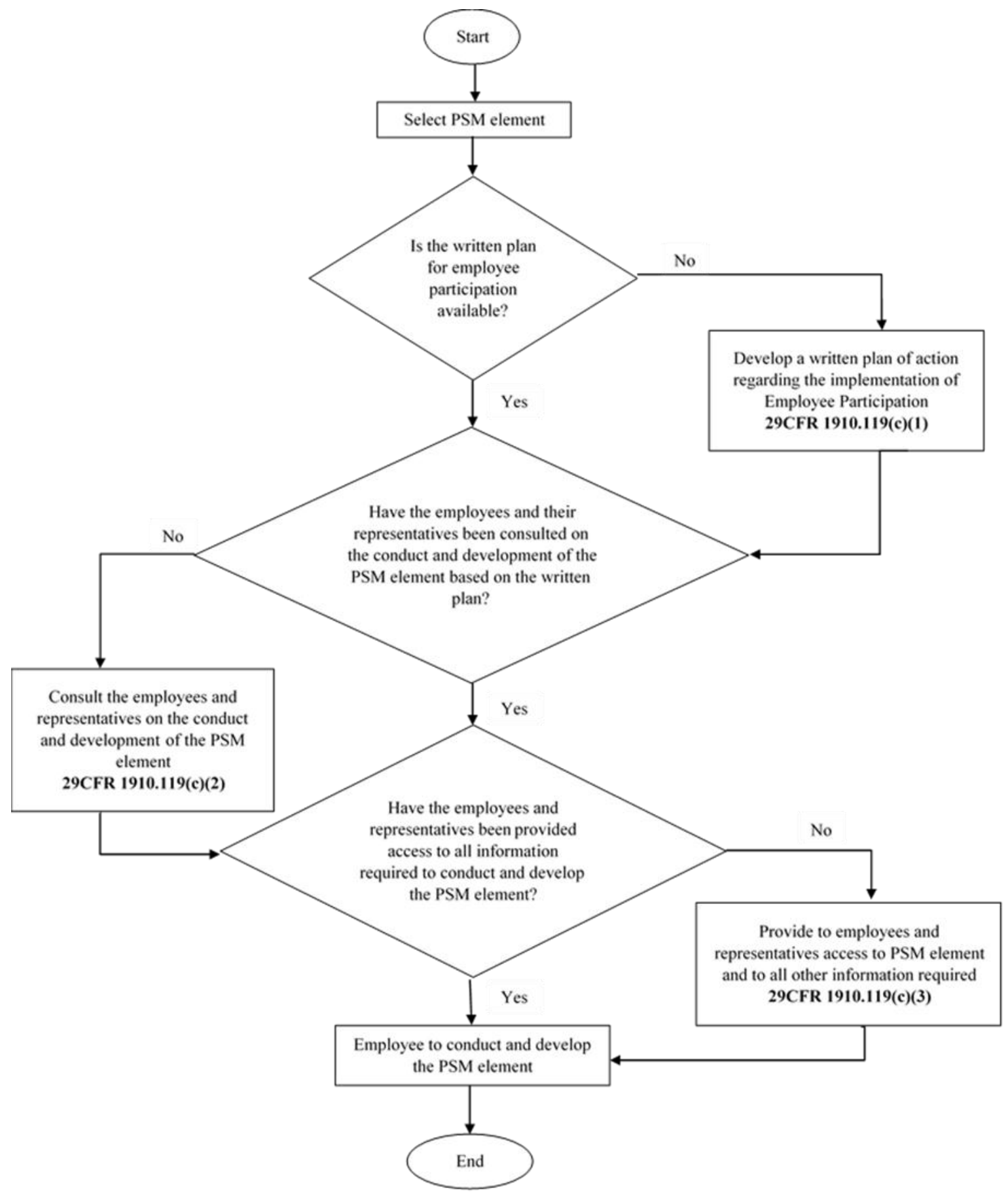

Fig. 1: Framework of Employee Participation based on OSHA CFR1910.119(c)

\subsection{Using Piping and Instrumentation Diagram as Foundation for Data Management}

Piping and Instrumentation Diagram (P\&ID) is used as the foundation as it incorporates details such as equipment and auxiliary and provides all the necessary information thoroughly without any possible missing information. The P\&ID is used as a platform for user to conduct gap analysis, manage information and document 
employee participation in a more structured manner. The P\&ID is divided into several nodes whereby a node is selected based on the process or design intent. Once the node has been selected as shown in Figure 2, the development and conduct of the Employee Participation for the selected PSM element can be initiated. Active participation of the employees is achieved as employees are provided with the details of information regarding their roles and responsibilities in accomplishing the conduct and development of the PSM element for the selected nodes according to the P\&ID.

The process is repeated at the same node until all the PSM ele- ments are completed for the conduct of Employee Participation. After Employee Participation is developed and conducted for all PSM elements within the node, then another node from the P\&ID will be chosen. The cycle continues for each node for the corresponding P\&ID. This approach is also used for model development of PHA, PSI, MI, TNG, HWP, CA, TS, CON and EPR elements of OSHA PSM [5-13].

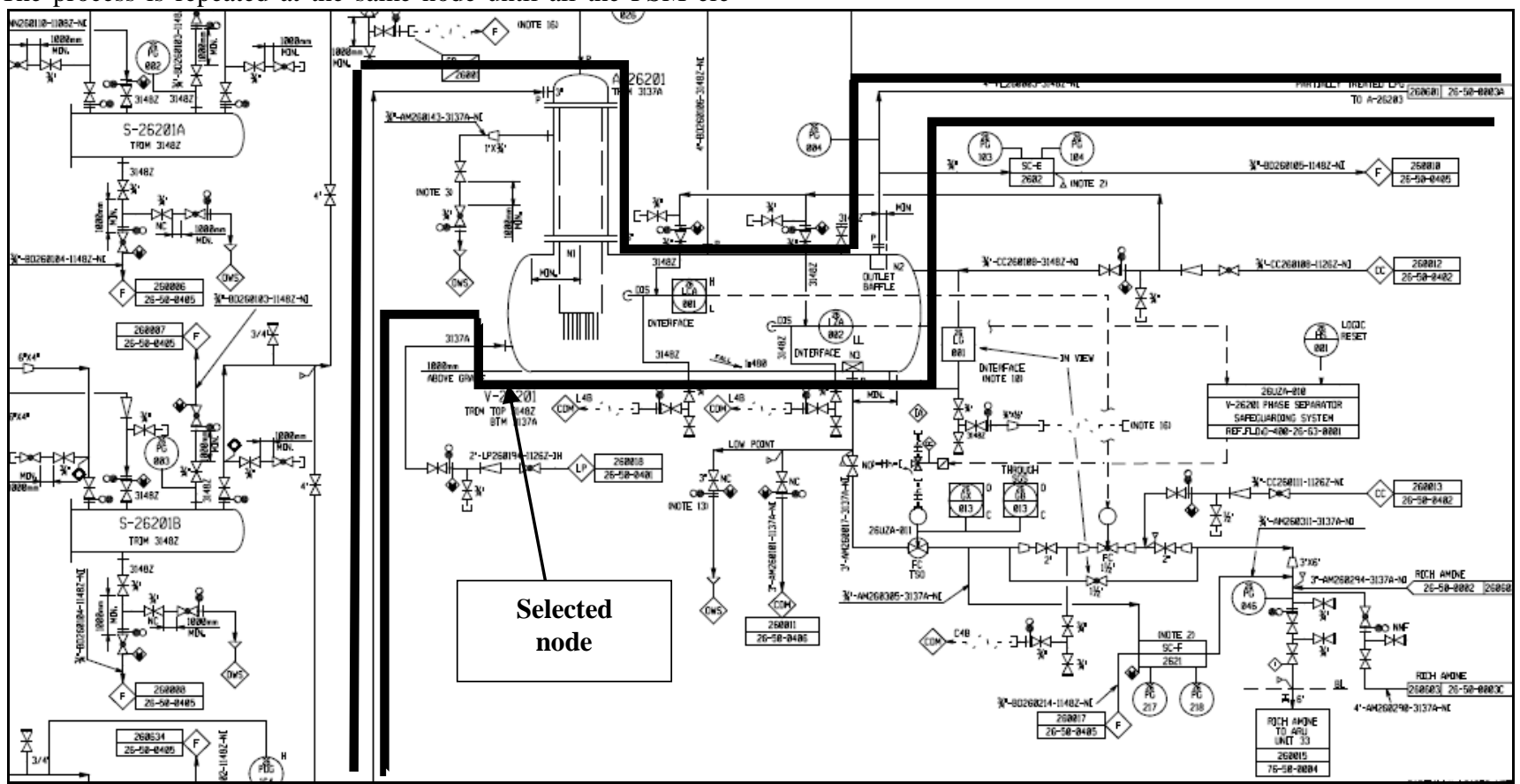

Fig. 2: Part of the Overall LPGU P\&ID Showing Phase Separator (V-201)

\subsection{Employee Participation Work-Aid Tool (EPWaT)}

The implementation of employee participation is further strengthened using a work-aid tool to manage the participations and responsibilities of employees within an organization. A prototype that utilizes Microsoft Access environment as database is developed by utilizing the framework established in Figure 1. The prototype name is Employee Participation Work-Aid Tool (EPWAT). The work-aid tool considers he requirement for employers and employees to commit to the OSHA PSM Employee Participation Standard. The work-aid tool is designed to ensure that the participation of employees in every activity is kept in a systematic manner for the ease of consultation and tracking of information. The work-aid tool is divided into 4 interfaces which are Main Interface, Written Plan, Consultation and Access to Information. Each interface has different objectives and provides information to conduct gap analysis and to determine how close the system complies with OSHA PSM requirements. The establishment of the system helps in assisting regulatory compliance and eases the auditing processes.

\section{Case Study}

In order to verify the proposed concept and practicability of the work-aid tool developed for employee participation, a case study was conducted using data from LPG treating unit (LPGU) of a refinery plant in Malaysia named Plant X. The LPG treating unit is a unit for removal of hydrogen sulfide $(\mathrm{H} 2 \mathrm{~S})$ and to reduce mercaptan (R-SH

in various LPG blend stock. The unit operates at a capacity of more than 10,000 pounds daily which is considered above the threshold quantity as stated in the OSHA PSM regulations. To demonstrate the concept of employee participation work-aid tool, one of the PSM elements i.e. Emergency Response Plan (ERP) was selected. Figure 2 shows the P\&ID for Plant $X$ which is used as the case study to validate the work-aid tool. The P\&ID is divided into several nodes, and node 1 has been selected for this case study. Node 1 represents a phase separator (V-201).

\subsection{Development of Employee Participation based on 29 CFR 10910.119(c)}

Figure 3 shows the main interface of EPM that consists of "Substandard", "Description", "Complete", "Incomplete", and "Remarks" columns. This interface acts as summary to the compliance status of all sub-standards under 29 CFR 1910.119(c). From Figure 3, the remarks column for sub-standard CFR 1910.119(c)(2) Consultation stated that the consultation data for emergency planning and response element was incomplete. 


\begin{tabular}{|l|l|c|c|c|}
\hline Main Interface & & & \\
\hline Sub-standard & Description & Complete & Incomplete & In \\
\hline 1910.119 (c)(1) & Written Plan & $\square$ & $\square$ & \\
\hline 1910.119 (c)(2) & Consultation & $\square$ & $\square$ & incomplete data on consultation for EPR element \\
\hline 1910.119 (c)(3) & $\begin{array}{l}\text { Access to } \\
\text { Information }\end{array}$ & $\square$ & $\square$ & \\
\hline
\end{tabular}

\subsection{Written Plan CFR 1910.119 (c)(1)}

Figure 4 displays the CFR 1910.119(c)(1) - Written Plan interface. This interface acts to check on the completeness and evidence of the written plan for every PSM elements. However, in the written plan itself, the company should address the minimum
Fig. 3: Main Interface of EPWAT

requirements for consultation on development of PHA and other elements. In addition, it should also address worker access to PHA, PSI and all documentations developed under PSM rule [14]. Sometimes, company may have the written plan of every element in the same document or separated to different documents.

\begin{tabular}{|c|c|c|c|c|c|c|c|c|c|c|}
\hline Main Interface & Written Plan Consulta & ation & nation & & & & & & & \\
\hline Standard & PSM Element & Document Title & - Evidence Location & - Complete & - Incomplete - & Revision - & Remarks & $\cdot$ & Action By - & - Due Date - \\
\hline $1910.119(\mathrm{~m})$ & Incident Investigation & $\begin{array}{l}\text { Employee } \\
\text { Responsibilities and } \\
\text { Participation in PSM } \\
\text { and RMP Programs }\end{array}$ & E:|user|generalinfo & $\square$ & $\square$ & $10 / 1 / 2014$ & & & & \\
\hline $1910.119(n)$ & $\begin{array}{l}\text { Emergency Planning and } \\
\text { Response }\end{array}$ & $\begin{array}{l}\text { Employee } \\
\text { Responsibilities and } \\
\text { Participation in PSM } \\
\text { and RMP Programs }\end{array}$ & E:|user|generalinfo & $\square$ & $\square$ & $10 / 1 / 2014$ & & & & \\
\hline 1910.119(o) & Compliance Audit & $\begin{array}{l}\text { Employee } \\
\text { Responsibilities and } \\
\text { Participation in PSM } \\
\text { and RMP Programs }\end{array}$ & E:luserlgeneralinfo & $\square$ & $\square$ & $10 / 1 / 2014$ & & & & \\
\hline 1910.1199(p) & Trade Secret & $\begin{array}{l}\text { Employee } \\
\text { Responsibilities and } \\
\text { Participation in PSM } \\
\text { and RMP Programs }\end{array}$ & E:|user|generalinfo & $\square$ & $\square$ & $10 / 1 / 2014$ & & & & \\
\hline
\end{tabular}

Fig. 4: Written Plan CFR 1910.119 (c)(1)

\subsection{Consultation CFR 1910.119 (c)(2)}

Figure 5 shows CFR 1910.119 (c)(2) - Consultation interface. This interface verifies on the consultation activities of PSM elements. Upon checking on one of the sub-standard e.g. Emergency
Action Plan (EAP) for the ERP element (Figure 6), it was found that the minutes of meeting and training records were not available. Thus, this remark was entered by user as input to the remarks column of Consultation interface of EPM.

\begin{tabular}{|c|c|c|c|c|c|c|c|c|c|}
\hline \multicolumn{10}{|l|}{ I Consultation } \\
\hline Standard . & PSM Element & Document Title & Evidence Location & - Complete - & Incomplete - & Remarks & $\cdot$ & Action by - & Due Date * \\
\hline $1910.119(\mathrm{~m})$ & Incident Investigation & & & $\square$ & $\square$ & & & & \\
\hline $1910.119(n)$ & $\begin{array}{l}\text { Emergency Planning } \\
\text { and Response }\end{array}$ & EPR Requirement for PSM & E:luser|PSMelement|EPR & $\square$ & 曰 & $\begin{array}{l}\text { minutes of meetings and training } \\
\text { records is not available }\end{array}$ & & EPR custodian & $9 / 30 / 2017$ \\
\hline 1910.1199(p) & Trade Secret & & & $\square$ & $\square$ & & & & \\
\hline
\end{tabular}

Fig. 5: Consultation CFR 1910.119 (c)(2) 


\begin{tabular}{|c|c|c|c|c|c|c|}
\hline \multicolumn{7}{|c|}{ EAP Sub-Standards } \\
\hline Standard & Requiremer - & Responsible Person/ Team - & Responsibilities & Document Title. & Document No/Locatior - & Remarks \\
\hline 1910.38 (c)1 & $\begin{array}{l}\text { Procedures } \\
\text { for reporting } \\
\text { a fire or other } \\
\text { emergency }\end{array}$ & $\begin{array}{l}\text { 1. Incident Commader (IC) } \\
\text { 2. Emergency Coordinator } \\
\text { 3. First Intervention Team } \\
\text { Leader (FITL) } \\
\text { 4. Shift Team Leader (STL) } \\
\text { 5. Public Information Officer } \\
\text { (PIO) }\end{array}$ & $\begin{array}{l}\text { 1. a) Communicate emergencies via walkie-talkie (channel 6/12) } \\
\text { b) Coordinate and mitigate the emergency through Emergency } \\
\text { Operation Centre (EOC) } \\
\text { 2. Communicate emergencies via walkie-talkie (channel 12) } \\
\text { 3. Communicate emergencies via walkie talk (channel 6) } \\
\text { 4. a)Received report/complaint from the public for an } \\
\text { incident/concern and can page the Public Information Officer (PIO) } \\
\text { to respond if required } \\
\text { b) Assign the Utility Panel Opertor to contact Duty Emergency } \\
\text { Support Team (EST) and Emergency Management Team (EMT) } \\
\text { members via the EMS Alert System. } \\
\text { 5. Deal or transfer the call requesting for information in case of } \\
\text { emergenceis of Tier } 2 / 3 \text { where Emergency Operation Centre (EOC) } \\
\text { have been activated. }\end{array}$ & $\begin{array}{l}\text { HSSE-ERP: Section } \\
8 \\
\text { Communications } \\
\& \text { control }\end{array}$ & $\begin{array}{l}\text { EPR D021/Document } \\
\text { room }\end{array}$ & $\begin{array}{l}\text { minutes of } \\
\text { meetings and } \\
\text { training records } \\
\text { is not available }\end{array}$ \\
\hline $1910.38(c) 2$ & $\begin{array}{l}\text { Procedures } \\
\text { for } \\
\text { emergency } \\
\text { evacuation, } \\
\text { including } \\
\text { type of } \\
\text { evacuation } \\
\text { and exit route } \\
\text { assignments }\end{array}$ & $\begin{array}{l}\text { 1. Chief Fire Marshall } \\
\text { Name: Zackaria Abdullah, } \\
\text { Location: SRC Main Office } \\
\text { Name: John Lim, Location: } \\
\text { Lube Oil Blending Plant } \\
\text { (LOBP), Production Mgt } \\
\text { 2. Fire Marshall } \\
\text { - Telephone Operator (SRC } \\
\text { Main Office, Ground Floor) } \\
\text { - Rizal Husin (SRC Main } \\
\text { Office, 1st floor) } \\
\text { - Mohd Sufian (SRC Main } \\
\text { Office, 2nd floor) }\end{array}$ & $\begin{array}{l}\text { 1. a) Coordinate all activities related to the ermgency including } \\
\text { evacuation, fire fighting and security. } \\
\text { b) Determine the location of the incident with Fire Marshalls or } \\
\text { from the local fire monitoring panel. } \\
\text { c) Receive and request reports fro, Fire Marshals. } \\
\text { d) Receive whether a search and rescue operation is to be mounted } \\
\text { for missing person. } \\
\text { 2. a) Ensure all personnel and visitors in area under charge evacuate } \\
\text { immediately to the nearest pre-determined assembly point upon } \\
\text { activation of alarm. } \\
\text { b) Ensure injured personnel are attended to by First Aiders. } \\
\text { c) Account for all personnel to ensure nobody is left behind and } \\
\text { initiate search where necessary. }\end{array}$ & $\begin{array}{l}\text { HSSE-ERP: Section } \\
8 \\
\text { Communications } \\
\& \text { control }\end{array}$ & $\begin{array}{l}\text { EPR D021/Document } \\
\text { room }\end{array}$ & $\begin{array}{l}\text { minutes of } \\
\text { meetings and } \\
\text { training records } \\
\text { is not available }\end{array}$ \\
\hline
\end{tabular}

Fig. 6: Consultation interface for the Emergency Planning and Response Element

\subsection{Access to Information CFR 1910.119 (c)(3)}

Figure 7 shows CFR 1910.119 (c)(3) - Access to Information interface. The interface captures data for easy monitoring of employee who have accessed the documents while developing and conducting the PSM elements without compromising its confidentiality status. Thus, this interface records the 'Document Title', 'Custodian of Documents', 'Access By/Position', 'Purpose', 'Date and Time Access' and 'Remarks' columns.

\begin{tabular}{|c|c|c|c|c|c|c|}
\hline Main Interface Written Plan & 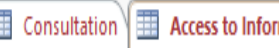 & rmation & & & & \\
\hline Document Title & - Custodian of Documents - & Access By/Position & Purpose & - DateAccess - & Time Access - & Remarks \\
\hline $\begin{array}{l}\text { HSSE-ERP: Section } 8 \\
\text { Communications \& control }\end{array}$ & Adly & Diana/internal EPR auditor & internal EPR audit & 1/13/2015 & 9:30:00 AM & \\
\hline $\begin{array}{l}\text { HSSE-ERP: Section } 8 \\
\text { Communications \& control }\end{array}$ & Adly & Samad/EPR element leader & $\begin{array}{l}\text { review documents } \\
\text { for audit }\end{array}$ & $11 / 27 / 2015$ & 10:00:00 AM & \\
\hline $\begin{array}{l}\text { HSSE-ERP: Section } 3.3 \text { Roles \& } \\
\text { Responsibilities }\end{array}$ & Adly & Joanne/ Training exacutive & $\begin{array}{l}\text { new staff training } \\
\text { purpose }\end{array}$ & $11 / 25 / 2015$ & 11:00:00 AM & \\
\hline
\end{tabular}

Fig. 7: Access to Information CFR 1910.119 (c)(3)

\section{Conclusion}

A systematic technique towards the Employee Participation implementation in process industries is presented throughout this work with the aim to comply with PSM CFR 1910.119 (c) requirements. A framework for Employee Participation has been developed based on PSM Standards, and a model has been developed based upon this framework. The model allows users to track documents or information easily and provide a basis for gap analysis to be carried out. This system assists users to better manage their Employee Participation in PSM implementation. This proposed technique can also be used by organizations and can be customized for the development of similar models in order to ensure that active participation of employees and ease the employers on providing consultation in real practice situations.

\section{Acknowledgement}

The authors would like to thank Universiti Teknologi PETRONAS Y-UTP grant (Cost Centre: 015 3AA E19) and Kementerian Pengajian Tinggi (KPT) - MyBrain-15 for the financial assistance given to the $\mathrm{PhD}$ student that makes this project feasible.

\section{References}

[1] Center for Chemical Process Safety, Guidelines for Risk Based Process Safety, 1st ed. John Wiley \& Sons, Inc., 2007.

[2] "OSHA PSM citations at manufacturer and distributor of chemicals (Ethylene Oxide \& \$80K)," 2016. [Online]. Available: http://www.safteng.net/index.php/free-section/safety-infoposts/chemical-process-safety-psmrmp/psm-a-rmp-citationsanalysis/4333-osha-psm-citations-manufacturer-and-distributor-ofchemicals-ethylene-oxide-80k. [Accessed: 29-Jun-2016].

[3] Occupational Safety \& Health Administration, "Process Safety Management Guidelines for Compliance," OSHA 3133, pp. 1-16, 1994.

[4] C. Cunio and G. Melhem, "A guide to the legal framework of the PSM standard for engineers," Process Saf. Prog., p. n/a-n/a, Oct. 2013.

[5] N. D. A. Majid, A. M. Shariff, R. Rusli, and K. I. Azman, "Trade Secret Model Based on OSHA Process Safety Management Requirement," Procedia Eng., vol. 148, pp. 1089-1095, 2016.

[6] N. D. Abdul Majid, A. Mohd Shariff, and S. Mohamed Loqman, "Ensuring emergency planning \& response meet the minimum Process Safety Management (PSM) standards requirements," $J$. Loss Prev. Process Ind., vol. 40, pp. 248-258, Mar. 2016.

[7] N. D. Abdul Majid, A. Mohd Shariff, and R. Rusli, "Process Safety Management (PSM) for managing contractors in process plant," $J$. Loss Prev. Process Ind., vol. 37, pp. 82-90, Sep. 2015.

[8] H. A. Aziz, A. M. Shariff, and R. Rusli, "Managing process safety information based on process safety management requirements," Process Saf. Prog., vol. 33, no. 1, pp. 41-48, Mar. 2014. 
[9] H. A. Aziz, A. M. Shariff, and R. Rusli, "Operational Training Management System (OPTRAMS) for Safe Operation in Process Plant.," Adv. Mater. Res., vol. 917, 2014.

[10] H. A. Aziz, A. Shariff, and M. Muhamad, "Development of Process Safety Management System (PSMS): Mechanical Integrity (MI)," Appl. Mech. Mater., vol. 625, pp. 486-489, Sep. 2014.

[11] N. D. A. Majid, A. M. Shariff, and E. S. B. Thiam, "Compliance Audit Model for Managing Process Safety in Process Industries," in Applied Mechanics and Materials, 2014, vol. 625, pp. 406-409.

[12] N. D. A. Majid, A. M. Shariff, and N. A. M. Zaki, "Compliance of Hot Work Permit to Process Safety Management (PSM) Regulation," in Applied Mechanics and Materials, 2014, vol. 625, pp. 418-421.

[13] H. A. Aziz, A. M. Shariff, and M. R. Roslan, "Managing process hazards in lab-scale pilot plant for safe operation," Am. J. Eng. Appl. Sci., vol. 5, no. 1, pp. 84-88, 2012.

[14] U. S. D. of Energy, DOE Handbook - Process Safety Management for Highly Hazardous Chemicals, vol. DOE-HDBK-1. Washington, D.C., 1996. 